\title{
Monitoring Sebaran Petugas Lapangan Citarum Harum dalam Pelaporan Digital
}

\section{Monitoring the Distribution of Citarum Harum Officers in Digital Reporting}

\author{
R Wisnu Prio Pamungkas*1, Rakhmi Khalida ${ }^{2}$ \\ 1,2 Jurusan Teknik Informatika Universitas Bhayangkara Jakarta Raya; Jl. Raya Perjuangan- \\ Bekasi Utara, 88955882

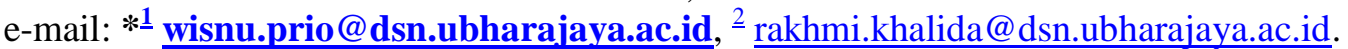

\begin{abstract}
Abstrak
Sampah jadi satu masalah dari sekian banyak masalah yang melanda Sungai Citarum, penyebab lainnya adalah limbah kimia. Pada kasus ini diperlukan tim pembersih sungai yang mengawal Sungai Citarum. Strategi sebaran petugas lapangan menjadi sangat penting, karena apabila ada sampah menyerang sungai dapat langsung ditangani. Tujuan penelitian ini adalah memaksimalkan peran petugas lapangan dalam mengawal Sungai Citarum, melakukan sosialisasi dan mengubah cara pandang masyarakat tentang lingkungan di sepanjang daerah aliran Sungai Citarum. Penelitian ini menggunakan sumber data primer dan sekunder. Metode perancangan sistem yang digunakan menggunakan metode prototype yaitu pengumpulan data, membangun prototype, evaluasi prototype, mengkodekan sistem, menguji sistem, evaluasi sistem, dan menggunakan sistem. Hasil yang dicapai pada penelitian ini berupa aplikasi monitoring persebaran petugas lapangan berbasis website dan android yang mampu mengetahui persebaran petugas lapangan pada daerah aliran Sungai Citarum. Pemanfaatan teknologi opensource tak berbayar ini membuat efektifitas, efisiensi, serta meningkatkan performa dalam pelaporan petugas lapangan sungai citarum.
\end{abstract}

Kata kunci - Sebaran data, Pelaporan, Petugas Lapangan, Sungai Citarum.

\begin{abstract}
Waste is a problem from many problems that hit the Citarum River, another cause is chemical waste. In this case a river cleaning team is required to guard the Citarum River. The strategy of distributing field officers is very important, because if there is waste attacking the river, it can be directly handled. The purpose of this study is to maximize the role of field officers in guarding the Citarum River, disseminating and changing the way people perceive the environment along the Citarum River basin. This study uses primary and secondary data sources. The system design method used uses the prototype method, which is collecting data, building prototypes, evaluating prototypes, coding systems, testing systems, evaluating systems, and using systems. The results achieved in this study were in the form of monitoring the distribution of website-based and android-based field officers who were able to find out the distribution of field officers in the Citarum River basin. The use of unpaid opensource technology makes effectiveness, efficiency, and improves performance in reporting officers of the Citarum river field.
\end{abstract}

Keywords - Data distribution, Reporting, Field Officers, Citarum River.

\section{PENDAHULUAN}

Sampah dan pembuangan limbah kimia jadi satu masalah dari sekian banyak masalah yang melanda Sungai Citarum. Pada kasus ini diperlukan tim pembersih sungai yang mengawal 
Sungai Citarum. Strategi persebaran petugas lapangan menjadi sangat penting, karena apabila ada sampah menyerang sungai dapat langsung ditangani. [1]

Demi mendukung program pemerintah pusat yang ditargetkan berjalan selama tujuh tahun, diperlukan sebuah sistem yang mendukung monitoring persebaran petugas lapangan. Pengunaan data akan bergerak dinamis sehingga monitoring persebaran tidak dapat lagi dilakukan secara konvensional. Perlu adanya sistem pendukung dan dukungan sumber daya yang memadai untuk meningkatkan performa dalam pelaporan petugas lapangan sebagai tindak lanjut sebuah proses kerja yang lebih optimal [2].

Penyebab lainnya pencemaran Sungai Citarum adalah kelemahan penegakkan hukum bagi pelaku pencemaran sungai dan keterbatasan infrastruktur dalam hal penyediaan data sistem monitoring [3]. Sistem berbasis database secara elektronik dapat memudahkan dalam penyediaan data, pengukuran kinerja, target, data yang akurat, relevan, dan tepat waktu untuk digunakan dalam pelaporan petugas lapangan kerja dan pengambilan suatu keputusan [4].

Dengan latar belakang masalah yang ada tersebut, maka monitor persebaran petugas lapangan perlu dibantu oleh sistem dalam membuat dan mengirimkan pelaporan yang realtime dan update. Sistem Pelaporan Petugas Lapangan Sungai Citarum yaitu sebuah sistem yang menjadi sarana dan prasarana yang sesuai akan kebutuhan pelaporan petugas lapangan sungai citarum. Penggunaan sistem ini dapat membantu percepatan kinerja petugas lapangan tersebut adalah dengan penggunaan aplikasi berbasis Android sebagai pembuatan dan pengiriman data dan informasi. Sedangkan untuk monitor persebaran petugas lapangan akan didukung oleh aplikasi berbasis website berbasis sistem informasi geografis [5]. dalam rangka monitoring dan evaluasi aktifitas yang dilakukan oleh petugas lapangan. Dengan adanya aplikasi ini diharapkan semua pihak terkait bisa secara menyeluruh mendapatkan laporan hasil kerja petugas lapangan yang update dan realtime secara terukur, efisien dan efektif, sehingga mendukung pengambilan suatu keputusan yang bijaksana.

\section{METODE PENELITIAN}

Penelitian menggunakan metode project life cycle dalam bentuk prototype yaitu dengan tahapan sebagai berikut : Pengumpulan data, membangun prototype, evaluasi prototype, mengkodekan sistem, menguji sistem, evaluasi sistem, dan menggunakan sistem [6].

a. Pengumpulan Data

Tahapan pengumpulan data dilakukan dengan mengumpulkan kebutuhan user requierement yang dilakukan dengan observasi dan dokumentasi terkait peranan akses aplikasi terhadap masing-masing user. Pada tahapan ini, menggali user untuk menjelaskan kebutuhan secara lengkap menjadi hal penting pada tahap di awal. Sehingga kebutuhan user tersebut dapat dikaitkan antar stakeholder satu dengan lainnya menjadi sebuah keutuhan informasi.

b. Membangun Prototype

Tahapan membangun prototype, merupakan tahapan yang berfokus pada penyajian pelanggan. Misalkan membuat input dan output hasil sistem [6]. Aktifitas ini menghasilkan spesifikasi fungsional.

Tahapan ini memerlukan evaluasi untuk mengetahui kemampuan sistem dengan mendefinisikan apa yang seharusnya dapat dilakukan oleh sistem tersebut kemudian menentukan kriteria yang harus dipenuhi sistem. Beberapa kriteria yang harus dipenuhi adalah pencapaian tujuan, kecepatan, biaya, kualitas informasi yang dihasilkan, efisiensi dan produktilitas, ketelitian dan 1aliditas dan kehandalan ataureliabilitas [5].

c. Evaluasi Prototype

Tahapan ini adalah aktivitas user melakukan evaluasi terhadap prototype yang telah dibangun, apakah sudah sesuai keinginan dan kebutuhan user atau belum. Apabila sudah sesuai dengan user, maka tahap selanjutnya dapat dilanjutkan yaitu mengkodekan sistem, tetapi apabila masih diperlukan perbaikan maka langkah pertama yaitu pengumpulan kebutuhan data dan langkah ke-dua membangun prototype harus dilakukan lagi. 
d. Mengkodekan Sistem

Dalam tahap ini prototype yang sudah disepakati diterjemahkan ke dalam bahasa pemrograman yang sesuai. Tahapan ini adalah tahapan membuat aplikasi laporan petugas lapangan berdasarkan dari tahapan-tahapan yang telah diselesaikan sebelumnya.

e. Menguji Sistem

Setelah sistem sudah menjadi suatu perangkat lunak yang siap pakai, sistem harus diuji dahulu sebelum digunakan. Pengujian ini dilakukan dengan Black Box.

f. Menggunakan Sistem

Perangkat lunak yang telah diuji dan diterima user siap untuk digunakan .

\section{HASIL DAN PEMBAHASAN}

Tahapan ini merupakan penjelasan detail metodologi pengembangan sistem menggunakan prototype.

\subsection{Ruang Lingkup Sistem}

Pengembangan aplikasi akan dilakukan dengan versi web dan android, sehingga perlu digali kebutuhan user terkait peranan akses aplikasi.

\subsubsection{Aplikasi Website}

Aplikasi berbasis web akan digunakan oleh user dengan jabatan manajer, supervisor dan pengawas lapangan.

a. Manajer

Aplikasi berbasis Web diantaranya berperan untuk :

i. Memberikan dan melihat validasi aktifitas harian, aktifitas lain, dan aktifitas fast respon petugas lapangan yang telah di validasi oleh supervisor dan pengawas lapangan

ii. Melihat sebaran petugas lapangan dengan memanfaatkan koordinat GPS pada handphone saat pengam bilan gambar di lapangan.

b. Supervisor

Aplikasi berbasis Web diantaranya berperan untuk :

i. Memberikan dan melihat validasi aktifitas harian, aktifitas lain, dan aktifitas fast respon petugas lapangan yang telah di validasi oleh pengawas lapangan, dan terkirim ke manajer.

ii. Melihat hasil validasi manajer atas aktifitas harian petugas lapangan dari laporan pengawas lapangan.

iii. Melihat sebaran petugas lapangan dengan memanfaatkan koordinat GPS pada handphone saat pengam bilan gambar di lapangan.

c. Pengawas Lapangan

Aplikasi berbasis Web diantaranya berperan untuk :

i. Memberikan aktifitas harian kepada petugas lapangan di bawahnya.

ii. Memberikan fast respon kepada petugas lapangan di bawahnya.

iii. Monitor daftar hadir harian.

iv. Monitor aktifitas harian.

v. validasi aktifitas harian, aktifitas lain, dan aktifitas fast respon petugas lapangan di bawahnya, dan terkirim ke supervisor sebagai atasanya langsung .

d. Admin user

Aplikasi berbasis web ini akan digunakan oleh berbagai tingkatan user yang diatur oleh admin user.

i. Update petugas lapangan sesuai jabatanya,

ii. Update user ke dalam Pengelompokan jenis user (Admin, pengawas lapangan, supervisor dan manajer)

iii. Update Jabatan

iv. Update Aktifitas sesuai Jabatan.

\subsubsection{Aplikasi Android}

Aplikasi berbasis android akan digunakan oleh petugas lapangan untuk hal-hal berikut 
a. Registrasi penggunaan aplikasi android dan membuat password user.

b. Melakukan aktifitas harian sesuai tugas pokoknya yang diperoleh dari pengawas lapangan

c. Melakukan aktifitas fast respon harian yang diperoleh dari pengawas lapangan.

d. Melakukan aktifitas lain-lain yang diperoleh secara lisan dari pengawas lapangan, atau inisiatif di lapangan.

e. Melihat history dari aktifitas yang Aktif | Sedang Proses | Sudah Selesai.

\subsection{Desain Database}

Desain database, dibuat untuk menyiapkan dasar kebutuhan database yang akan digunakan untuk persiapan aplikasi yang dibutuhkan dalam proses penyimpanan dan transaksi data (Gambar 1). Dalam komunikasi database antar aplikasi yang dibutuhkan sebagai bentuk Webservice, API akan menyebutkan data apa saja yang akan dibutuhkan dari database aplikasi android dengan database aplikasi laporan website.

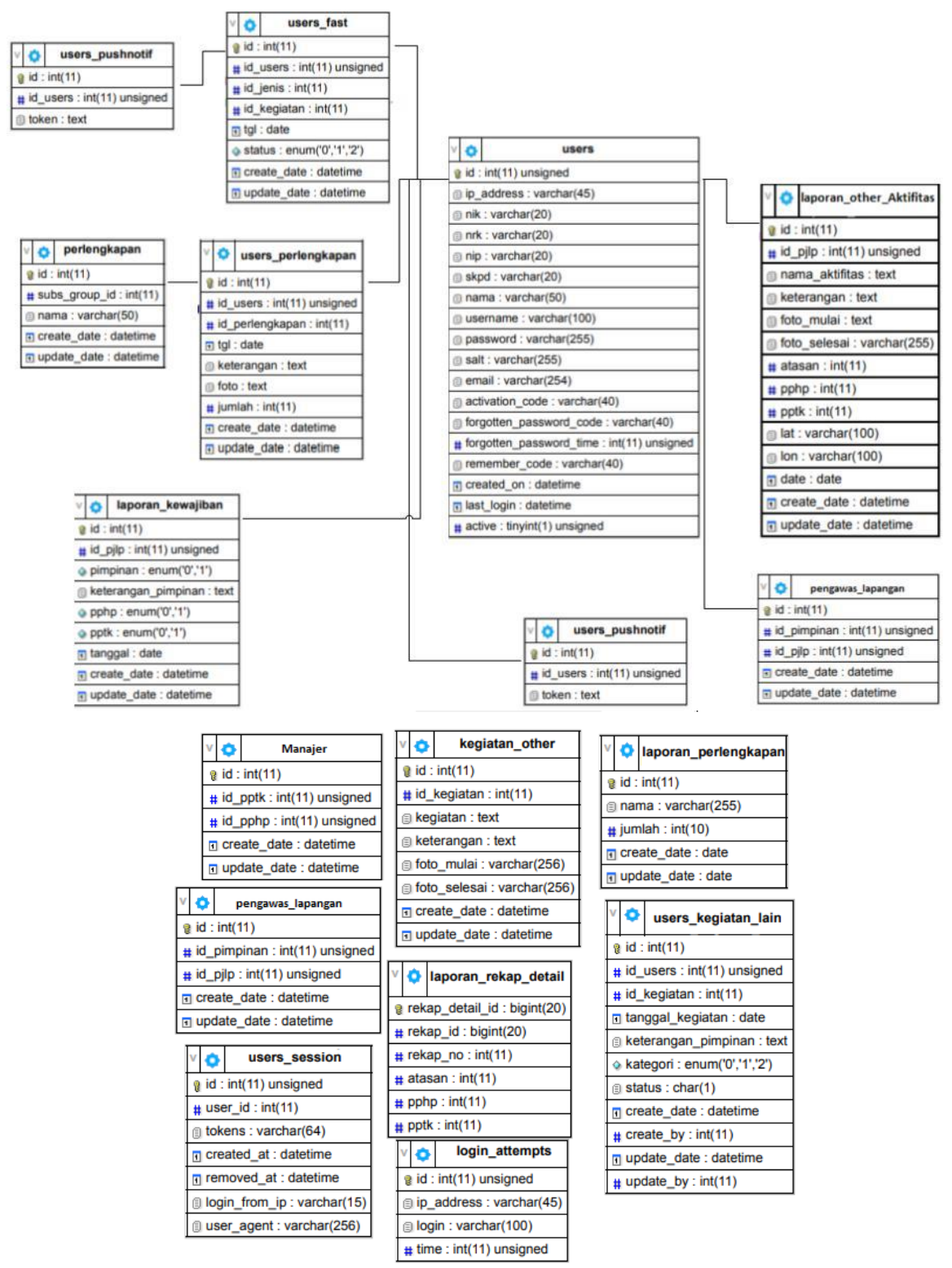

Gambar 1. Desain Database 


\subsection{Desain Sistem}

Aplikasi yang dibangun adalah Sistem terintegrasi antara web laporan, android laporan dan database terpusat. Sehingga aplikasi yang dibangun dapat digunakan untuk kebutuhan lain yang dapat diintegrasikan dengan aplikasi lain yang dapat memanfaatkan data yang ada, seperti pemanfaatan kordinat data pada foto, dapat digunakan sebagai data lokasi / peta dari pengguna. Untuk desain dengan UML jenis Use Case dapat ditampilkan pada penjelasan selanjutnya.

\subsubsection{Aplikasi Website}

Seperti pada tahapan perencanaan di atas, terdiri dari user pengawas lapangan, supervisor dan manajer serta Admin / Super User.

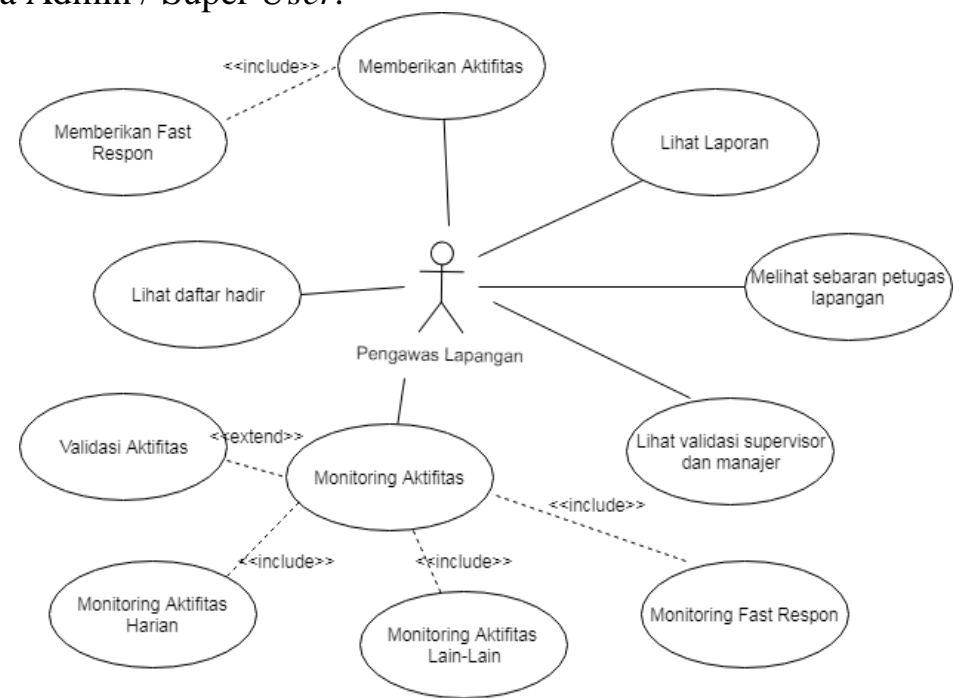

Gambar 2. Use Case Pengawas Lapangan

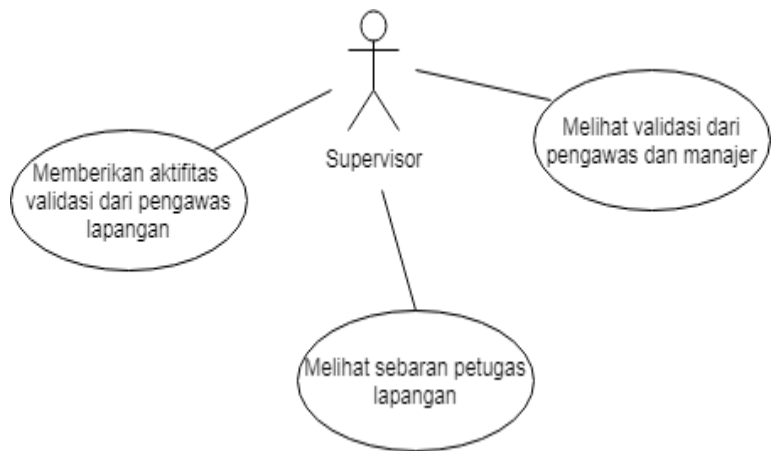

Gambar 3. Use Case Supervisor

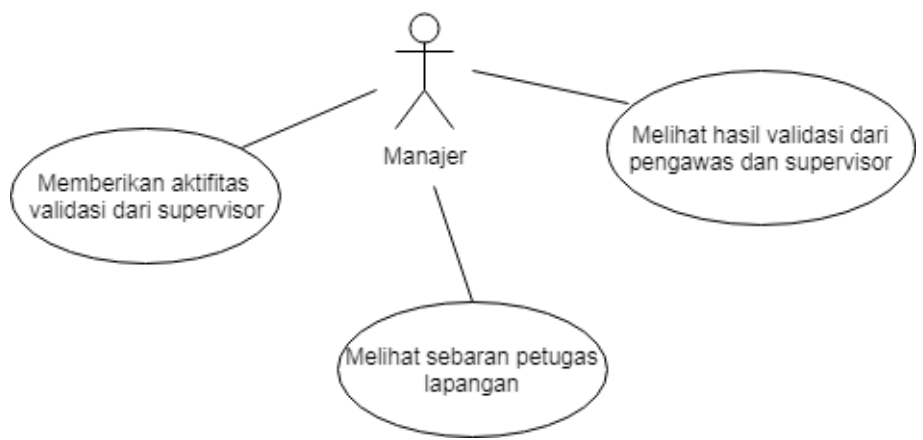

Gambar 4. Use Case Manajer 


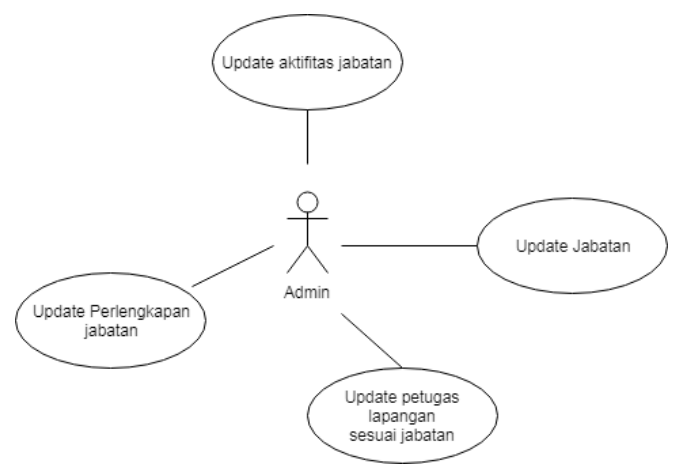

Gambar 5. Use Case Admin

\subsubsection{Aplikasi Android}

Seperti pada tahapan Perencanaan di atas, terdiri dari kegiatan seorang petugas lapangan..

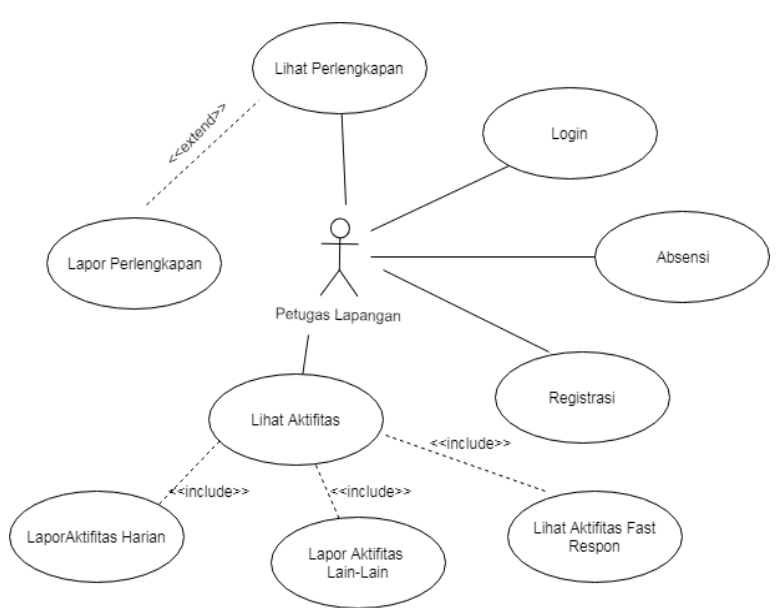

Gambar 6. Use Case Petugas Lapangan

\subsection{Arsitektur Sistem}

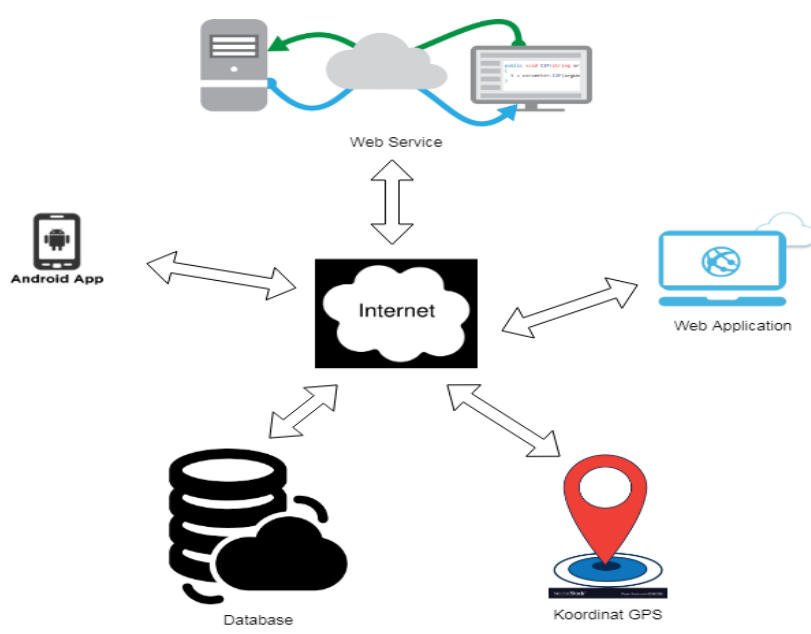

Gambar 7. Arsitektur Sistem 
Gambar di atas menunjukan arsitektur sebuah sistem aplikasi monitoring sebaran petugas lapangan. Aplikasi terbagi menjadi 2 bagian, yaitu:

1. Aplikasi berada di sisi client yang berkomunikasi dengan server mengandalkan jaringan internet. Aplikasi di sisi client yang berbasis website dan berbasis android bisa di akses dengan dukungan dari web services. Web services menyediakan bussiness logic, proses, dan data yang dibutuhkan. Aplikasi berbasis web akan digunakan oleh manajer, supervisor, dan pengawas lapangan untuk validasi semua kegiatan dari petugas lapangan. Selain itu, aplikasi dapat digunakan untuk melihat atau monitor aktifitas dari petugas lapangan dan melihat posisi sebaran petugas lapangan sesuai kordinat yang disimpan dari GPS pada Handphone yang digunakan dalam mengirimkan data ke server.

2. Aplikasi Android akan digunakan untuk proses aktifitas petugas lapangan sesuai dengan tugas pokok masing-masing bagian petugas lapangan. Selain itu dapat mengakomodasi kebutuhan dalam kehadiran (melalui pencatatan waktu) dan lokasi (melalui pencatatan gps) untuk kegiatan dari petugas lapangan, sehingga petugas lapangan dapat mengerjakan tugas-tugas yang diberikan Pengawas lapangan terhadap dirinya secara akurat, aktual dan terpercaya. Database, merupakan lokasi data yang akan digunakan sebagai penyimpanan data maupun penggunaan data transaksi aplikasi. Koordinat GPS, adalah spesifikasi fungsional yang diimplementasikan melalui geotag handphone saat pengambilan foto sebagai laporan aktifitas petugas lapangan.

\subsection{Uji Coba Aplikasi}

Skenario yang dilakukan adalah menggunakan metode blackbox Melalui prosedur Alpha Test menjadi perlakuan uji coba akan disesuaikan secara aturan Business Process dari aplikasi.

Tabel 1. Uji Sistem Metode Blackbox

\begin{tabular}{|c|c|c|c|c|}
\hline No & Jenis Aplikasi & Test Case & $\begin{array}{l}\text { Hasil yang } \\
\text { diharapkan }\end{array}$ & Keterangan \\
\hline 1 & Website & Pengujian halaman login & $\begin{array}{l}\text { Sistem akan } \\
\text { memproses form } \\
\text { apabila username } \\
\text { dan password } \\
\text { yang diisi adalah } \\
\text { benar }\end{array}$ & Berhasil \\
\hline 2 & & $\begin{array}{l}\text { Pengujian halaman monitor } \\
\text { kehadiran petugas lapangan }\end{array}$ & $\begin{array}{l}\text { Sistem } \\
\text { menampilkan } \\
\text { data dari tabel } \\
\text { kehadiran yang } \\
\text { telah diisi melalui } \\
\text { perangkat } \\
\text { android petugas } \\
\text { lapangan. }\end{array}$ & Berhasil \\
\hline 3 & & $\begin{array}{l}\text { Pengujian halaman monitor } \\
\text { sebaran posisi petugas } \\
\text { lapangan }\end{array}$ & $\begin{array}{l}\text { Sistem } \\
\text { menampilkan } \\
\text { peta DAS } \\
\text { Citarum dan } \\
\text { terdapat data } \\
\text { koordinat dari } \\
\text { foto laporan yang } \\
\text { dibuat petugas } \\
\text { lapangan }\end{array}$ & Berhasil \\
\hline 4 & Android & Pengujian halaman login & $\begin{array}{l}\text { Sistem akan } \\
\text { memproses form } \\
\text { apabila username } \\
\text { dan password } \\
\text { yang diisi adalah }\end{array}$ & Berhasil \\
\hline
\end{tabular}


Monitoring Sebaran Petugas Lapangan ...

\begin{tabular}{lll}
\hline & & benar \\
\cline { 3 - 3 } & Pengujian halaman utama & Petugas dapat \\
& mengakses semua \\
& fungsi pada menu \\
& utama apabila \\
& ingin bekerja \\
& membuat laporan \\
\hline
\end{tabular}

\subsubsection{Aplikasi Website}

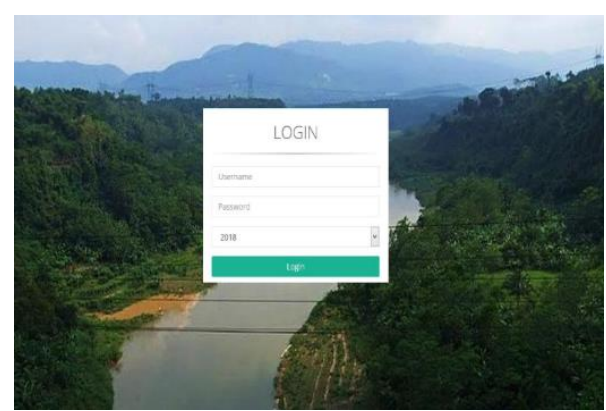

Gambar 8. Halaman Login Aplikasi Web

Halaman login ini, dibuat dengan bentuk pilihan jenis user. Ada beberapa pilihan yaitu:

1. Admin

2. Manajer

3. Supervisor

4. Pengawas Lapangan

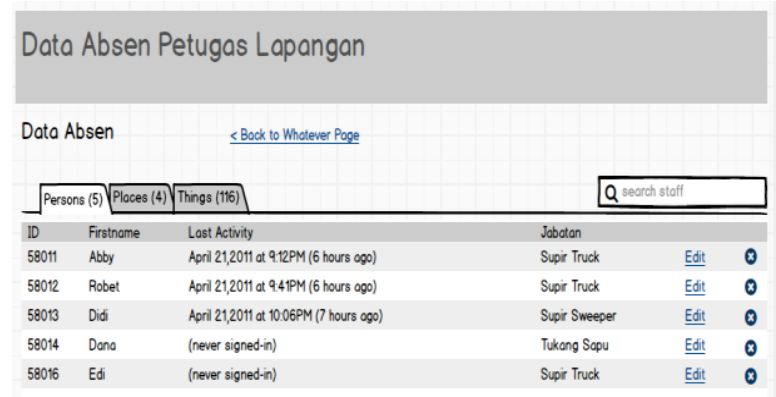

Gambar 9. Data Absensi Petugas Lapangan

Menampilkan data absensi dari petugas lapangan di bawah pengawas lapangan. Dengan menampilkan data petugas lapangan dengan ID nya, bila di klik link tersebut akan memunculkan waktu login dan logout tiap waktunya di hari tertera. 


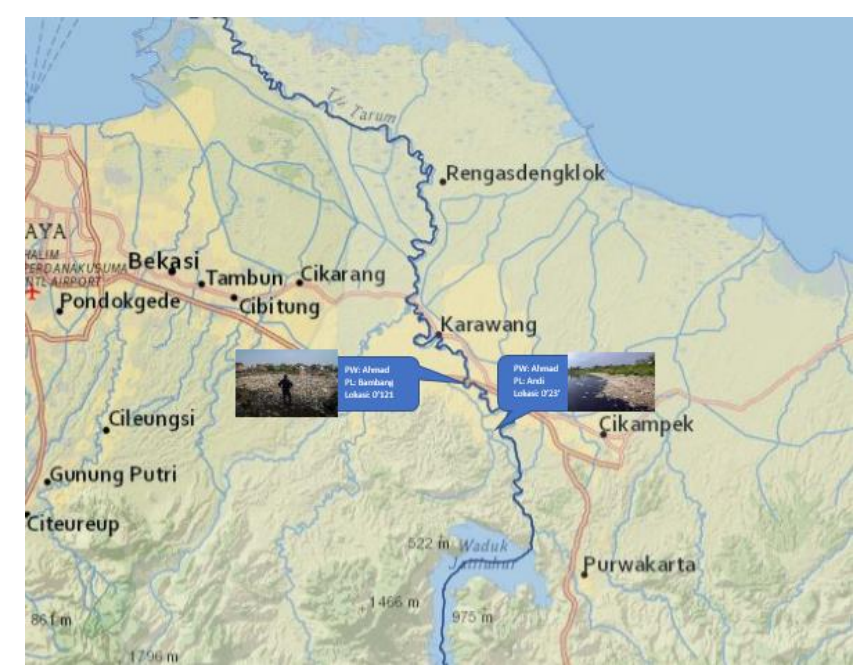

Gambar 10. Menu Sebaran Lokasi Petugas Lapangan

Menampilkan posisi sebaran petugas lapangan yang dapat dillihat secara otomatis apabila petugas lapangan telah melaporkan aktifitasnya.

\subsubsection{Aplikasi Android}

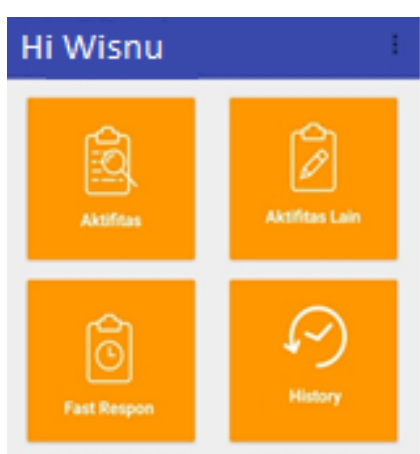

Gambar 11. Halaman Utama Aplikasi Android

Tampilan menu di atas sebagai menu-menu aplikasi adalah kegiatan yang dilakukan dari petugas lapangan dengan menampilkan menu-menu sesuai kebutuhan, yaitu:

1. Aktifitas

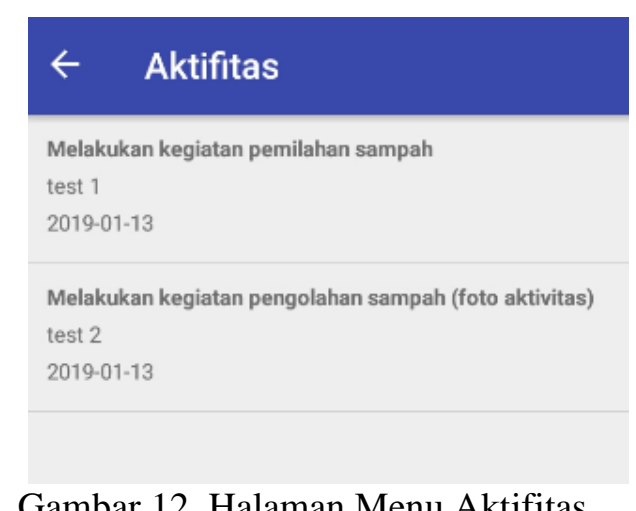

\section{Gambar 12. Halaman Menu Aktifitas}

berfungsi untuk mengerjakan aktifitas rutin atau kegiatan rutin petugas lapangan dari pengawas lapangan yang dikirim secara rutin oleh sistem. 
2. Aktifitas Lain

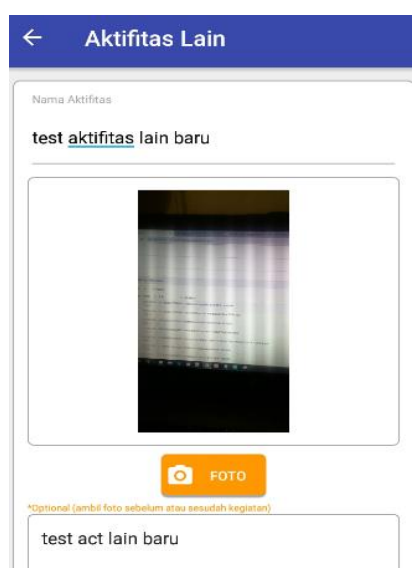

Gambar 13. Halaman Menu Aktifitas Lain

Merupakan menu untuk mencatat dan melaporkan aktifitas lain selain kegiatan atau aktifitas rutin dari petugas lapangan.

3. Fast Respon

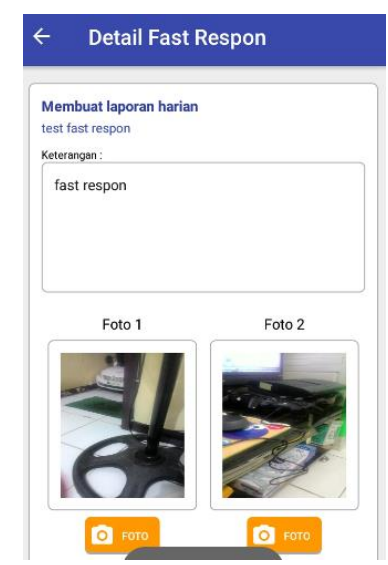

Gambar 14. Halaman Menu Fast Respon

Aktifitas ad-hoc dari Pengawas lapangan yang perlu segera direspon oleh petugas lapangan setelah muncul tanda / notifikasi sebagai pesan baru di handphone yang perlu untuk segera ditindak lanjuti.

4. History

Berisi daftar kegiatan dari petugas lapangan, baik yang belum dikerjakan, sedang berjalan dan sudah selesai dari masing-masing aktifitas petugas lapangan tersebut. 


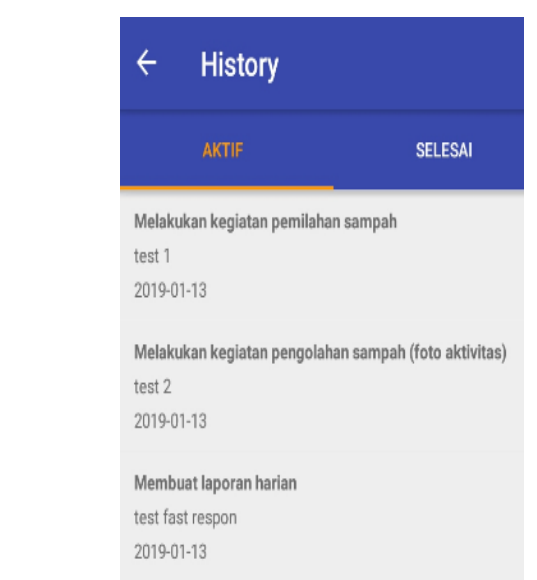

Gambar 15. Halaman Menu History

\section{KESIMPULAN}

Aplikasi dibangun sesuai kebutuhan dari user dalam hal ini adalah petugas lapangan daerah Sungai Citarum. Ruang lingkup aplikasi website bagi pengguna sebagai pengawas lapangan, supervisor dan manajer serta Admin atau Super User digunakan untuk melakukan monitor laporan dan monitor sebaran petugas lapangan agar memaksimalkan peran petugas lapangan dalam mengawal Sungai Citarum serta melakukan sosialisasi dan mengubah cara pandang masyarakat tentang lingkungan di sepanjang daerah aliran Sungai Citarum dan peran petugas lapangan dalam aplikasi Android dapat memudahkan pengawas, supervisor, dan manajer melakukan monitor daerah aliran Sungai Citarum.

Dapat digunakan sebagai penanda kehadiran dari peserta petugas lapangan, setelah melakukan login, melakukan transaksi harian sebagai aktifitas dan geotag foto yang diambil dari handphone di dalam laporan aktifitas yaitu dengan membuat titik sebaran dapat dimonitor pengawas lapangan, supervisor dan manajer.

\section{SARAN}

Saran dari kegiatan ini, setelah aplikasi ini dapat digunakan, ada baiknya lanjut ke sosialisasi dan bimbingan teknis bagi pengguna lainnya. Setelah itu, perlu dikembangkan dari data sesuai dengan informasi kebutuhan user.

\section{DAFTAR PUSTAKA}

[1] Peraturan Presiden Republik Indonesia No. 15 Tahun 2018, tentang Percepatan Pengendalian Pencemaran dan Kerusakan Daeraha Aliran Sungai Citarum

[2] Dina. 2018. Evaluasi Program Investasi Pengelolaan Sumber Daya Air Terpadu Citarum. Jurnal Academia Praja, No.1, Vol. 1.

[3] Dyah, M., Dwina, R., Pradono., Arwin, S., 2013, Diferensiasi Sumber Pencemar Sungai Menggunakan Pendekatan Metode Indeks Pencemaran (IP) (Studi Kasus: Hulu DAS Citarum). Jurnal RISET Geologi dan Pertambangan, No.1, Vol 23, 41-52.

[4] Edhy Sutanta, 2012. Sistem Basis Data: Konsep dan Perananya dalam Sistem Informasi Manajemen.: Andi Offset, Yogyakarta.

[5]. Prapitasari, L.P.A., Sumiari, N.K., Jayanti, N.K.D.A. 2016. Sistem Informasi Geografis Pasar Tradisional di Wilayah Denpasar menggunakan Framework YII. Sisfotenika, No.2 Vol. 6.

[6] Agus mulyanto. 2009. Perancangan Sistem Informasi dan Aplikasinya.penerbit pustaka belajar.Yogyakarta . 